CLINICAL STUDY

\title{
Significance of low levels of thyroglobulin in fine needle aspirates from cervical lymph nodes of patients with a history of differentiated thyroid cancer
}

\author{
Anne-Laure Borel, Robert Boizel, Patrice Faure ${ }^{1}$, Geneviève Barbe ${ }^{1}$, Jean Boutonnat ${ }^{2}$, Nathalie Sturm ${ }^{2}$, \\ Daniel Seigneurin ${ }^{2}$, Ivan Bricault ${ }^{3}$, Jean-Pierre Caravel ${ }^{4}$, Philippe Chaffanjon ${ }^{5}$ and Olivier Chabre \\ Endocrinology, CHU Albert Michallon and Université Joseph Fourier, 38043 Grenoble, France ${ }^{1}$ Integrated Biology, ${ }^{2}$ Anatomy and Cell Pathology, \\ ${ }^{3}$ Radiology, ${ }^{4}$ Nuclear Medicine and ${ }^{5}$ Thoracic and Endocrine Surgery, CHU, 38043 Grenoble, France \\ (Correspondence should be addressed to O Chabre who is now at Endocrinologie, CHU, BP 217X, 38043 Grenoble Cedex O9, France; \\ Email: olivierchabre@chu-grenoble.fr)
}

\begin{abstract}
Objective: Measurement of thyroglobulin in the washout of lymph node (LN) fine needle aspirates is recommended in the follow-up of patients with differentiated thyroid cancer (DTC). The significance of low fine needle aspirates thyroglobin (FNATg) levels remains a question, which we addressed. Method: Prospective study comparing FNATg with FNA cytology. Exploration of 34 DTC patients (53 cervical LNs), 26 non-thyroidectomized patients with a thyroid-unrelated cervical mass (negative controls) and 13 with 21 thyroid nodules (positive controls). The 12 DTC patients (19 LNs) with a malignant FNA cytology and/or high FNATg level received LN surgery (11 patients) or I ${ }^{131}$-iodine treatment (1 patient) and the outcome measure was pathological or scintigraphic evidence of DTC LN metastasis.

Results: All 26 negative controls showed FNATg $<1 \mathrm{ng} / \mathrm{FNA}$ and all 21 positive controls showed high levels of FNATg (127-210 000 ng/FNA, median 38 000). Among DTC patients in 25 LNs with a benign FNA cytology, FNATg was undetectable in 24 and low in 1 ( $6 \mathrm{ng} / \mathrm{FNA})$; in 19 LNs with a malignant FNA cytology, FNATg was high in 17 (80-140 000 ng/FNA, median 7174 ng/FNA) and low in 2 (6.6 and $7.1 \mathrm{ng} / \mathrm{FNA}$ ), which proved to be low Tg immunostaining oncocytic DTC metastasis; in 9 LNs with a noninformative cytology, FNATg was undetectable in 8 but $11825 \mathrm{ng} / \mathrm{FNA}$ in 1, which proved a DTC metastasis. Measurement of FNA albumin demonstrated that contamination of FNA by serum proteins was negligible.

Conclusion: Low FNATg levels can indicate a DTC metastasis. It cannot be related to clinically relevant levels of serum $\mathrm{Tg}$.
\end{abstract}

European Journal of Endocrinology 158 691-698

\section{Introduction}

Patients with differentiated thyroid carcinoma (DTC) may develop recurrences many years after initial surgery, essentially metastatic neck lymph nodes (LNs) (1), so that a long-term follow-up is required. The different tools available for this follow-up include basal and thyrotrophin (TSH)-stimulated serum $\mathrm{Tg}$, neck ultrasonography (US), and LN fine needle aspiration biopsy with cytological analysis (FNAB). None of these tools are perfect: serum $\mathrm{Tg}$ has a very high specificity for the detection of recurrences $(2,3)$ but its sensitivity on thyroxine treatment, which is improved by TSH stimulation, is not optimal for detecting small LN metastases. It is unreliable in patients with circulating thyroglobulin antibodies $(\mathrm{TgAb})$ and another issue is that it does not localize neoplastic foci. The specificity of neck US is not optimal, although it has recently been improved by the identification of several features whose association is highly specific for malignancy (4). Fine needle aspiration cytology has an excellent specificity (5) but a suboptimal sensitivity, especially in cystic metastatic LNs (6). To improve sensitivity of FNA, several authors proposed to measure $\mathrm{Tg}$ in the washout of the needle used for FNA (FNATg), and a limited number of studies indeed reported that FNATg could improve sensitivity of FNA cytology (7-9). Consequently, European guidelines recommended the association of FNATg with cytology examination when FNA is performed $(10,11)$. Very recently, a large retrospective study reported a promising 100\% sensitivity and 96\% specificity of FNATg using a low cut-off value of $1 \mathrm{ng} / \mathrm{ml}$ (12) and another study reported similar results in the exploration of LNs in a non-thyroidectomized patient suspected to have DTC (13).

Different questions regarding this technique still need to be solved. Firstly, several authors have reported the presence of detectable $\mathrm{Tg}$ in non-metastatic cervical LNs $(7,12,14)$, a finding that affects the specificity of the method. Secondly, FNATg methodology is not 
standardized, with all studies showing significant differences in the manner of performing the needle washout, the assay used for measurement of $\mathrm{Tg}$ and the way of expressing the results of $\mathrm{Tg}$ measurement (per FNA or per ml). Finally, the possibility of interferences between $\mathrm{Tg}$ and $\mathrm{TgAb}$ in the FNA washout was noted in all studies but addressed only in one (13).

The objective of this study was to bring new data to help clarify these questions: we used a simple methodology to perform FNA washout and FNATg measurement, and we validated it in the follow-up of 34 DTC patients ( $53 \mathrm{LNs}$ ) against FNA cytology, using 26 negative and 21 positive controls. LNs with a malignant FNA cytology and/or high FNATg levels underwent surgery or $\mathrm{I}^{131}$-iodine treatment, allowing either pathological evidence of DTC metastasis and a measure of the $\mathrm{Tg}$ immunostaining of the removed LNs or scintigraphic evidence of DTC metastasis. We also addressed the question of potential interference with serum Tg or TgAb.

\section{Patients and methods}

\section{Patients}

Between October 2003 and June 2007, 34 consecutive patients, previously treated by total thyroidectomy for DTC (31 papillary carcinoma and 3 follicular carcinomas), were referred to the multidisciplinary thyroid cancer concertation unit of the University Hospital of Grenoble for the appearance, during follow-up, of neck LNs with suspicious features on neck US (see below), with or without basal of TSH-stimulated detectable serum Tg. In addition, one patient with a thyroid nodule suspect of papillary carcinoma on FNA cytology was explored by LN FNA cytology and Tg before thyroidectomy (which showed pathological evidence of DTC and LN DTC). An ultrasound-guided FNA of all suspicious LNs $(n=53)$ was performed, allowing for both cytologic examination and FNATg. Albumin and $\mathrm{TgAb}$ were also measured in the washout and concomitant serum $\mathrm{Tg}$ and $\mathrm{TgAb}$ were collected through the patients' medical history. Pathological examination with $\mathrm{Tg}$ immunostaining of the LNs was performed when surgery was indicated, by the presence of positive FNA cytology and/or positive FNATg.

A negative control group was constituted by measuring $\mathrm{Tg}$ in the washout of 26 FNAs that were realized in 26 consecutive patients with no history of DTC or any other thyroid disease, who were referred to the department of cytology for the exploration by FNA of a neck mass. A positive control group was constituted by measuring $\mathrm{Tg}$ in the washout of 21 FNA that were realized in 13 consecutive patients referred to the endocrine unit for exploration by FNA of one or several thyroid nodules $(n=21)$. In both the control groups, the measurement of FNATg after FNA had no interference with the exploration of these patients. The characteristics of the different groups are shown in Fig. 1.

In this study, DTC patients received only the examination recommended for follow-up of DTC patients. In the control patients, the only exploration performed in this study was on the needle used for FNA. The decision for proceeding with FNA was not related to this study and the result of FNATg did not interfere by any means with the medical care of the patients.

\section{Ultrasonography (US)}

US was performed on the cervical area (Acuson-computed sonography 128 XP/10 Siemens, Berlin, Germany or Aplio, Toshiba, Japan). Features suspicious of metastatic neck LNs included abnormal round shape, size above $5 \mathrm{~mm}$, intralesional calcifications, central location, cystic changes, and loss of echogenic hilum (15).

\section{FNA washout}

FNA was US guided and performed with BD spinal needles (22 GA: $0.7 \times 38 \mathrm{~mm}$, Becton Dickinson SA, Madrid, Spain) when the mass depth was above $1 \mathrm{~cm}$. In such cases, the stylet was left in while advancing the needle, in order to prevent the aspiration of extranodal tissue from the needle tract. In other cases, BD Microlance 3 Needles (23 GA: $0.6 \times 25 \mathrm{~mm}$, Becton Dickinson SA) were used, with or without US assistance, according to the discretion of the operator. Then the cells were spread on a glass slide and $1 \mathrm{ml}$ saline physiological serum $(0.9 \% \mathrm{NaCl}$; Aguettant, Lyon, France) was aspirated through the needle with a syringe from a test tube $(2 \mathrm{ml}$ microtubes PP, Sarstedt, Nümbrecht, Germany). To validate the use of saline solution rather than the Tg-free solution given by the measurement kit, we performed measurements of $\mathrm{Tg}$ immunoreactivity in samples containing only Tg-free solution, saline solution, or saline solution supplemented with $70 \mathrm{~g} / \mathrm{l}$ human serum albumin. We observed that $\mathrm{Tg}$ immunoreactivity was below detection limit in each sample and conclude that there should be no matrix effect in this assay related to the use of saline rather than Tg-free medium for dilution of the fine needle aspirates. Preliminary experiments on the FNA washout of three patients with thyroid nodules showed that a triple pumping action of the original $1 \mathrm{ml}$ serum through the needle was sufficient to wash $>97 \%$ of $\mathrm{Tg}$ out of the needle. Indeed, the measurement of $\mathrm{Tg}$ in a second washout performed with another $1 \mathrm{ml}$ serum showed $\mathrm{Tg}$ levels to be $<3 \%$ of the $\mathrm{Tg}$ from the first washout $(55000,540000$, and $850000 \mathrm{ng} / \mathrm{FNA}$ in the first washout of each nodules FNA; 1500, 12000 , and $21000 \mathrm{ng} / \mathrm{FNA}$ in the second washout respectively). After the triple pumping action through the needle, the washout was left in the test tube that was then closed and sent to the laboratory for biological analysis. 


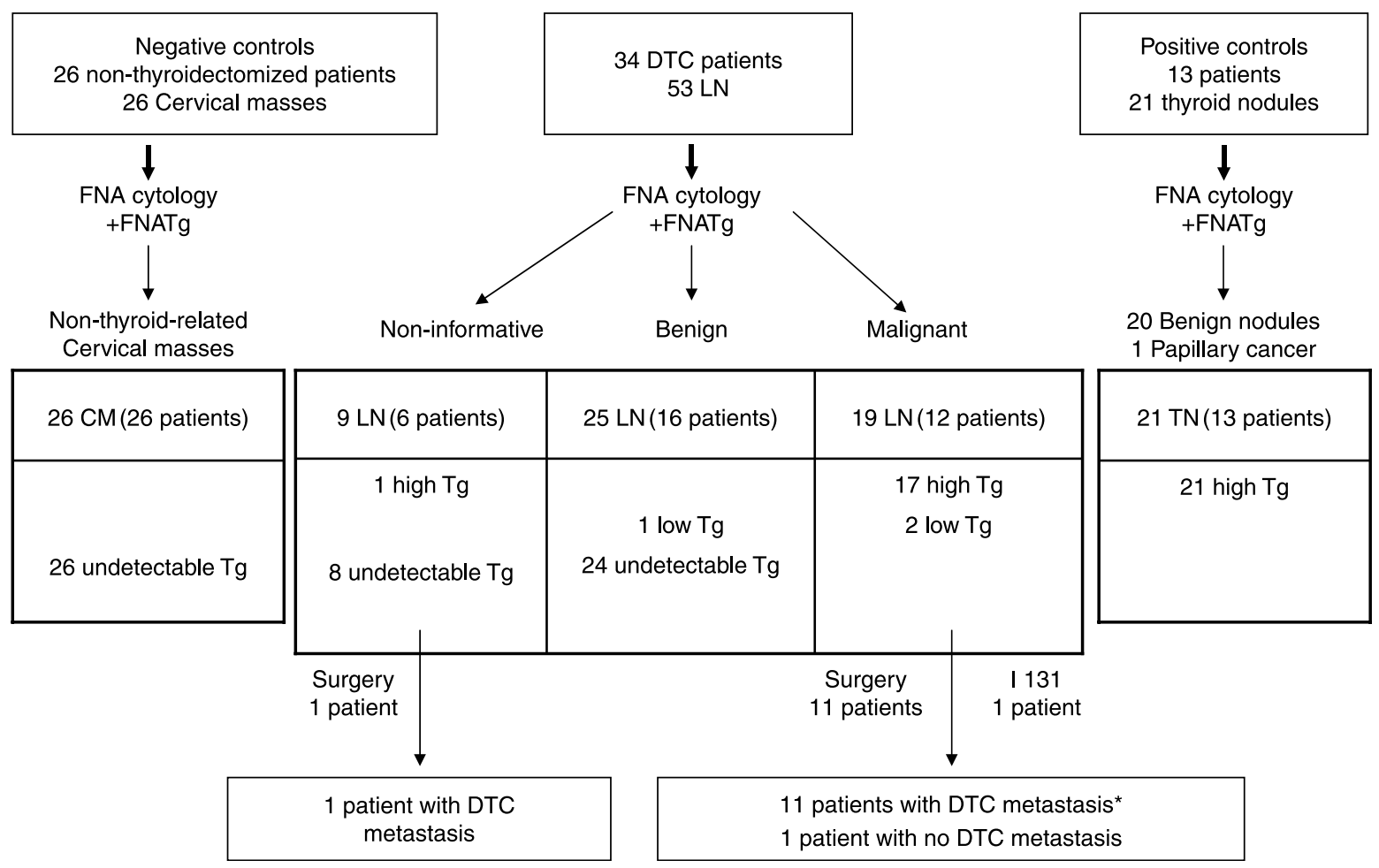

Figure 1 Study design and patients. 'High Tg' are FNATg levels within the range of thyroid nodules FNATg above 10 ng/FNA. 'Low Tg' are FNATg levels that are detectable but well below the range of thyroid nodules FNATg $10 \mathrm{ng} / \mathrm{FNA}$. Undetectable Tg are FNATg values below detection limit (1 ng/FNA). *The two LNs with a malignant cytology and low levels of FNATg proved to be low Tg immunostaining oncocytic DTC metastasis. DTC, differentiated thyroid cancer; LN, lymph node; TN, thyroid nodules; CM, cervical masses; FNATg, fine needle aspirates thyroglobin.

\section{Biological measurements}

Thyroglobulin measurements in the FNA washout and serum were performed with an IRMA (Kit Cis Bio International, Gif-sur-Yvette, France); $\mathrm{TgAb}$ was measured with a radioimmunoassay (Brahms International, Brasov, Romania) with a functional sensitivity of $20 \mathrm{U} / \mathrm{ml}$. Tg assays were run at two dilutions or more in order to search for a putative hook effect. Results of serum Tg and FNATg were expressed in ' $\mathrm{ng} / \mathrm{ml}$ ' and 'ng/FNA' respectively, with a functional sensitivity of $1 \mathrm{ng} / \mathrm{ml}$ or $1 \mathrm{ng} / \mathrm{FNA}$ (inter-assay coefficient variation of $20 \%$ ). To express the results of FNATg, we decided to use ng/FNA, as the 'inventors' of the technique in 1992 (7) (Table 1). We consider that the unit ng/FNA is appropriate as what is studied here is the quantity of Tg left in the needle after puncture and washed during the washout. Since 1992 several authors have used $\mathrm{ng} / \mathrm{ml}$ (Table 1 ) that may falsely induce the reader to believe that FNATg reflects a concentration of Tg in the LN, whereas it actually reflects the dilution of the quantity of $\mathrm{Tg}$ left in the needle in the volume of solution used for the washout. Albumin was measured by immunoprecipitation (BN II Dade Behring, Marburg, Germany), with the calibration curve used with urinary samples to measure the minute quantity of protein anticipated in the washout liquid. The functional sensitivity was $10 \mu \mathrm{g} / \mathrm{l}$.

\section{Histological analysis}

Surgical specimens, with LN dissection labeled according to site and side, were fixed in $10 \%$ formalin and embedded in paraffin. Sections of $4 \mu \mathrm{m}$ were then stained routinely with hematoxylin-eosin-safran (HES). LN status was assessed by gross and histological examination. LNs with size $\geq 0.5 \mathrm{~cm}$ were crosssectioned and each embedded separately, while the smaller ones were embedded together. Five serial sections of each LN were performed and examined histologically.

\section{Statistical analysis}

Normality tests (skewness, kurtosis, and omnibus tests) concluded to a non-Gaussian distribution of FNATg values. All results are therefore expressed as medians (interquartile, range). Multiple comparisons were carried out with non-parametric Kruskal-Wallis tests following by post hoc analyses when the results of Kruskal-Wallis tests were significant. All statistical analyses were completed with the NCSS 97 statistical 


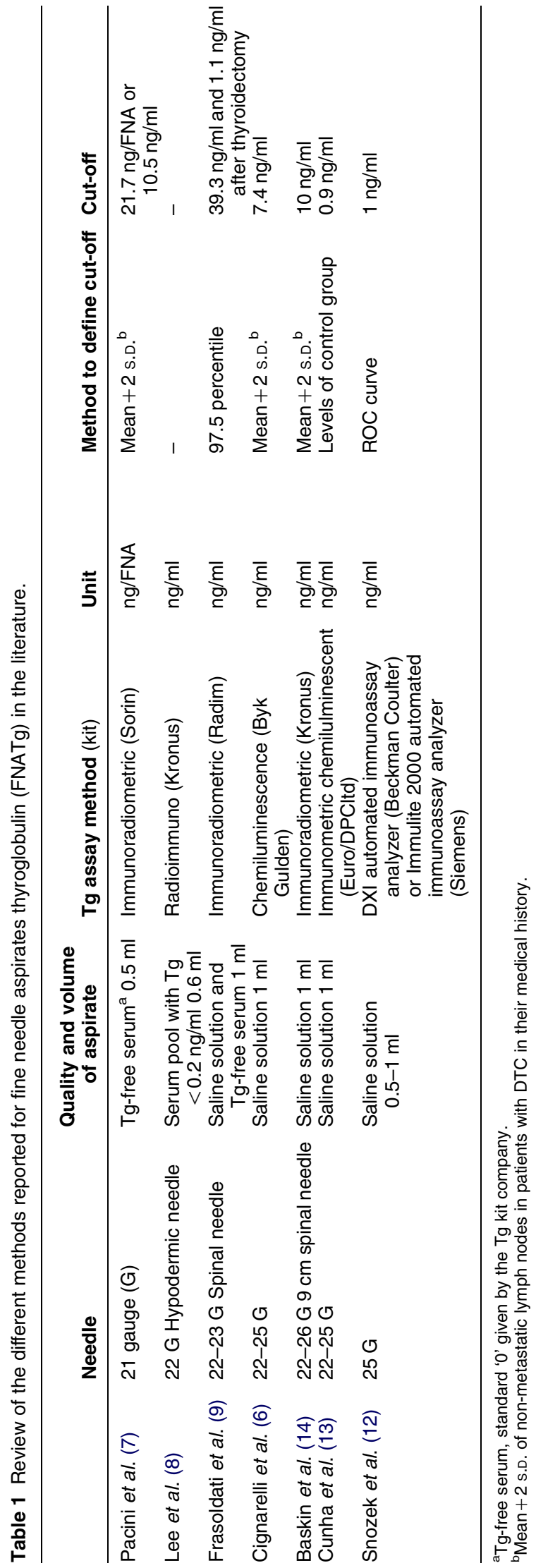

software (Kayesville, UT, USA). A value of $P<0.05$ was considered statistically significant.

\section{Results}

\section{Cytological results}

Cytological results are summarized in Fig. 1.

In the negative control group, all 26 cervical mass FNA cytologies were informative. Five cervical masses depended on the parotid, one was a post-surgical collection, and nineteen were non-DTC-related LNs (11 infectious LNs and 8 tumorous LNs). The pathological examination was in agreement with the cytological conclusions in all surgically removed cervical masses.

In the positive control group, FNA cytology classified 20 thyroid nodules as benign and 1 as a papillary carcinoma, which was confirmed by histological examination after thyroid surgery.

In the 53 LNs from 34 patients with a DTC history, cytology was informative in $44 \mathrm{LNs}$, including $25 \mathrm{LNs}$ (16 patients) classified as benign with no thyroid cells and 20 LNs (12 patients) as malignant with the presence of neoplastic thyroid cells. It was noninformative in nine LNs (six patients).

\section{Thyroglobulin levels in FNA}

FNATg is shown in Fig. 2 for all groups. We classified FNATg levels as undetectable when below the detection limit ( $<1 \mathrm{ng} / \mathrm{FNA})$; low when the level of FNATg was between detection limit and $10 \mathrm{ng} / \mathrm{FNA}$, which is close to the cut-off level used by previous reports (Table 1) and high when it was above this cut-off level.

Negative control group In all 26 cervical mass of these non-thyroidectomized patients, FNATg was undetectable.

Positive control group In the 21 thyroid nodules, FNATg was always high with a median of $38000 \mathrm{ng} / \mathrm{FNA}$ (25th, 11 850; 75th, 93 500; range 127-210 000).

DTC patients: In the 25 LNs (16 patients) with a benign FNA cytology, FNATg was undetectable in 24 LNs (15 patients) and detectable but low in $1 \mathrm{LN}$ (1 patient), $6 \mathrm{ng} / \mathrm{FNA}$. This patient underwent a second FNA of the same LN after 1 year: it showed a poorly informative but benign cytology and this time FNATg was undetectable.

In the 19 LNs (12 patients) with a malignant cytology, the median FNATg was 7174 ng/FNA (25th, 1363; 75th, 25 302; range 6.6-140 000), in the range of positive controls except for two LNs (1 patient) that showed low levels of FNATg (6.6 and $7.1 \mathrm{ng} / \mathrm{FNA}$ ).

In the nine LNs with a non-informative result, eight had FNATg below detection limit but one LN showed an 


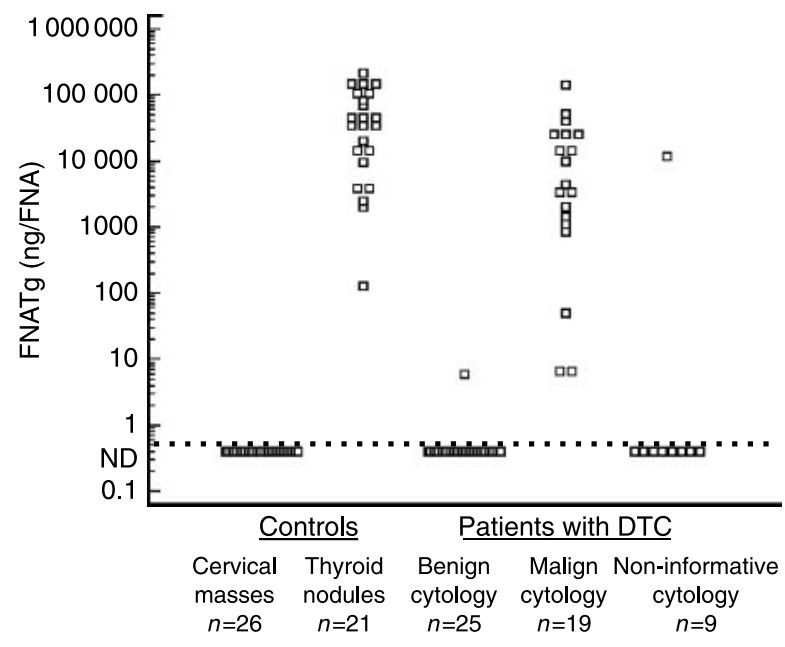

Figure 2 FNA thyroglobulin levels in patients and control subjects. The $y$-axis has a logarithmic scale. The dotted-line represents the detection limit for $\mathrm{Tg}$ in this method $(1 \mathrm{ng} / \mathrm{ml}$ or $1 \mathrm{ng} / \mathrm{FNA}$ when FNA washout is measured in $1 \mathrm{ml}$ ). ND, non-detectable Tg. In patients with a DTC history, the difference in FNATg levels in metastatic versus nonmetastatic lymph nodes is highly significant $(P<0.001)$. FNATg levels are not significantly different in between metastatic lymph nodes versus thyroid nodules and in between non-metastatic lymph nodes versus cervical masses from patients with no DTC history.

FNATg of $11825 \mathrm{ng} / \mathrm{FNA}$, equivalent to the $25 \mathrm{th}$ percentile of positive controls and higher than the median observed in DTC patients with a malignant LN cytology.

\section{Histological results}

Out of the 12 patients (20 LNs) with a malignant cytology, 11 patients underwent LN surgery and one underwent radioiodine therapy without LN surgery. None of the 16 patients (25 LNs) with a benign cytology underwent LN surgery, in agreement with international recommendations. In these patients, we cannot provide evidence of benign histology. Consequently, false negative of FNA cytology associated with FNATg cannot be excluded. In addition, the patient with a non-informative cytology but an FNATg of $11825 \mathrm{ng} / \mathrm{FNA}$ underwent LN surgery, so that histological results were available in 12 patients and scintigraphic results in 1 patient (Fig. 1). Pathological examination confirmed DTC LN metastases in 11 out of the 12 patients, including 10 out of the 11 patients with a malignant cytology and the patient with a noninformative cytology but an FNATg of 11825 ng/FNA. In one of the 12 patients with a malignant LN FNA cytology, no DTC LN metastasis was identified, despite preoperative malignant FNA cytology and a high FNATg (52 000 ng/FNA).

The levels of expression of $\mathrm{Tg}$ immunostaining varied widely between patients with a very low immunostaining in the DTC metastasis of the oncocytic DTC that showed the very low levels of FNATg. The $\mathrm{Tg}$ immunostaining also varied between different areas of the same sample in a given patient (Fig. 3).

\section{Evaluation of the contamination of FNATg by serum $\mathbf{T g}$}

DTC patients We made the following 'worst-case hypothesis': all the volume of material aspirated through the syringe would be blood, all the $\mathrm{Tg}$ contained in the material would first not be washed out of the needle when the material is spread on the glass, and then entirely recovered in the washout of the needle by the saline solution. The quantity of serum $\mathrm{Tg}$ aspirated through the needle is then the concentration of serum $\mathrm{Tg}(\mathrm{ng} / \mathrm{ml})$ multiplied by the volume of the material $(\mathrm{ml})$, which proved to be $<0.2 \mathrm{ml}$. Using this hypothesis, one can calculate that a patient with a $20 \mathrm{ng} / \mathrm{ml}$ serum $\mathrm{Tg}$ should have a maximal contamination of FNATg by serum $\mathrm{Tg}=20 \times 0.2=4 \mathrm{ng} / \mathrm{FNATg}$. We then used the values of serum Tg to calculate what could be the contamination of FNATg by serum Tg in our DTC patients who had at least a detectable FNATg. This included 15 patients: the 12 patients with a malignant cytology, 2 with a benign cytology, and 1 with a non-informative cytology (Fig. 1). From these 15 patients, 14 had one or several determination of serum $\mathrm{Tg}$, which was detectable in 7 patients, in the range of $0.4-29.2 \mathrm{ng} / \mathrm{ml}$, whereas FNATg was in the range of 49-140 000 ng/FNA (Fig. 4). So one can calculate that the maximal contamination of FNATg by serum Tg should be $29.2 \times 0.2=5.8 \mathrm{ng} / \mathrm{FNA}$. It should be noted, however, that the DTC patient with the serum Tg value of $29.2 \mathrm{ng} / \mathrm{ml}$ had an FNATg of $14400 \mathrm{ng} / \mathrm{FNA}$, so that a potential contamination of FNATg by $5.8 \mathrm{ng}$ serum Tg $(0.04 \%)$ is clearly not significant in this patient. Using the same calculation in each of these 14 DTC patients, we could calculate that the maximal contamination of FNATg by serum Tg varied between 0.003 and $0.012 \%$, clearly not significant in any patient.

Negative controls Because the 26 negative controls were not thyroidectomized we know they do have a detectable serum Tg, although the data are not available. All 26 patients had an undetectable FNATg that demonstrate that their serum $\mathrm{Tg}$ has not interfered with FNATg.

Measurement of FNA albumin In order to measure the contamination of LN washout by plasma proteins, albumin levels were measured in the washouts of 24 LNs FNA from DTC patients, including 9 LNs which proved to be DTC metastasis. FNA albumin was from 0.02 to $2.18 \mathrm{mg} / \mathrm{FNA}$. Comparison of these values with the normal serum concentration of albumin, $40 \mathrm{mg} / \mathrm{ml}$ demonstrates that the maximal contamination of FNA by serum protein in this study is a ratio of 0.05 versus serum, lower than our hypothesis of a 0.2 ratio (see above).

In conclusion, theoretical considerations as well as experimental data support the hypothesis that serum $\mathrm{Tg}$ did not interfere in any results of FNATg presented in this study. 

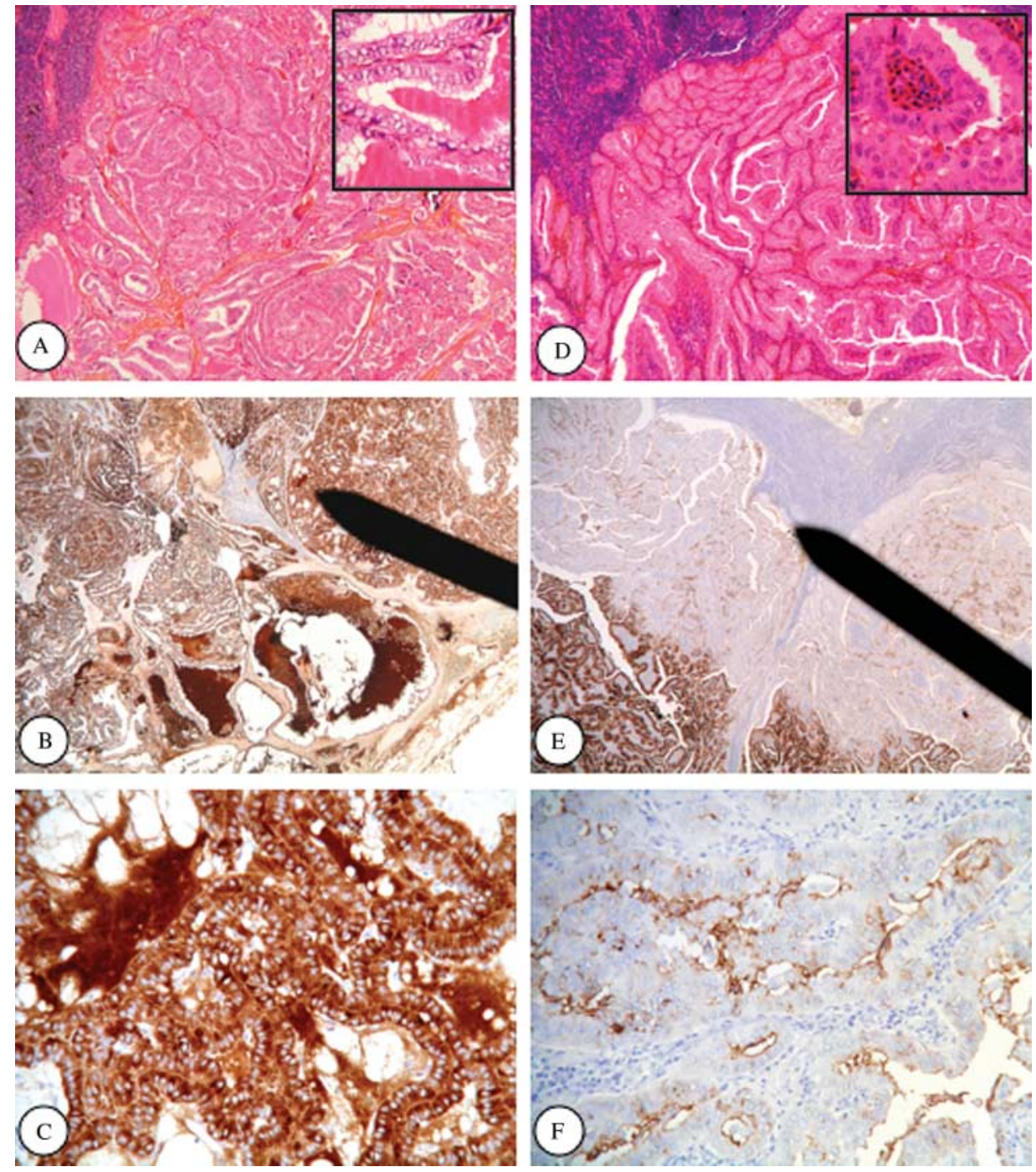

Figure 3 Differences in the levels of thyroglobulin immunoreactivity in (A-C) a classical papillary thyroid carcinoma lymph node metastasis with a high level (140 $000 \mathrm{ng} / \mathrm{FNA}$ ) of FNATg versus (D-F) an oncocytic variant with a low level (6 ng/FNA) of FNATg. In both the cases, the patients had neck lymph node surgery after FNA and a lymph node metastasis was found at pathological examination. The tip of the needle used for FNA was put under the microscope and photographed with the histological slice in B and $E$ to allow for a visual evaluation of the size of the cell sampling by the needle. (A) Papillary thyroid carcinoma lymph node metastasis in its most characteristic form with typical papillae and nuclear changes. The high magnification at the top right shows cuboidal and columnar carcinomatous cells with typical overlapped groundglass nuclei (HES $\times 40$ and 400). (B) Intense and diffuse thyroglobulin immunoreactivity in the carcinomatous proliferation and also in the intraluminal colloid $(\times 40)$. (C) High magnification showing diffuse intracytoplasmic immunostaining in cuboidal and columnar carcinomatous cells $(\times 200)$. (D) Oncocytic variant of papillary carcinoma, composed of large carcinomatous cells magnified at the top right, with large granular eosinophilic cytoplasm and numerous nuclear pseudoinclusions. There is no colloid (HES $\times 400)$. (E) Thyroglobulin immunoreactivity is focal, heterogeneous, and very weak in some areas $(\times 40)$. (F) High magnification showing faint and apical polarized cytoplasmic immunostaining in oncocytic carcinomatous cells $(\times 200)$.

\section{Possibility of TgAb interference with FNATg measurement in the washout}

In all patients with an undetectable FNATg, $\operatorname{TgAb}$ measurement in the FNA washout was negative, even in six patients with high levels (range 48-1000 UI/ml) $\mathrm{TgAb}$ in the serum. In patients with a detectable FNATg, $\mathrm{TgAb}$ was negative when FNATg was lower than 2000 ng/FNA. When FNATg was higher, the measurement of $\mathrm{TgAb}$ in the washout was a false positive because of the very high level of thyroglobulin. Indeed, this artifact is a known competitive effect when $\mathrm{Tg}$ is higher than $1450 \mathrm{ng} / \mathrm{ml}$.

\section{Discussion}

There are several reasons why measurement of LN FNATg should be a sensitive and specific tool for the detection of LN DTC metastasis in patients followed for 


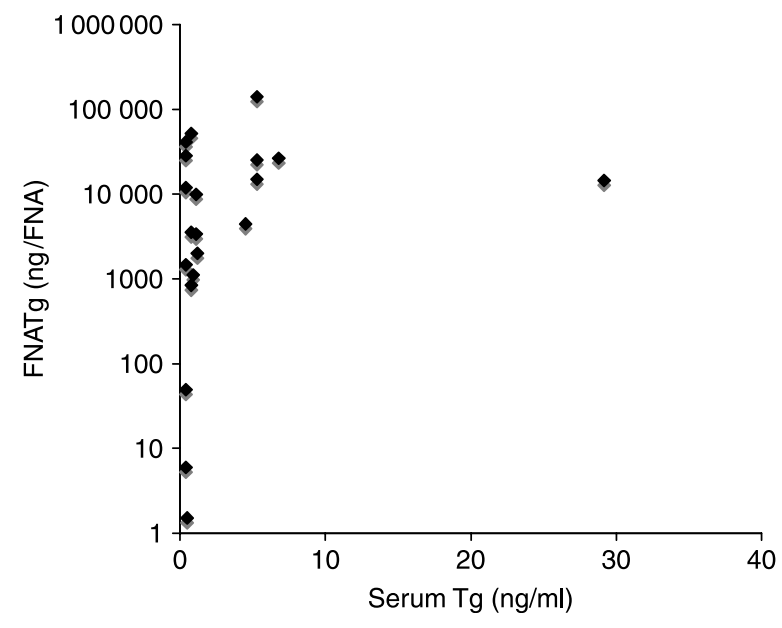

Figure 4 Comparison of FNATg with serum Tg in 12/13 DTC patients with DTC LN metastasis. For 18 results of LN FNATg (12 patients), the results of FNATg were plotted against the corresponding serum Tg.

DTC. Regarding sensitivity, concentration of Tg is very high in thyroid vesicles, and it is found both inside the thyrocytes and in its close vicinity, allowing to identify the proximity of thyroid cells even if no cells are actually identified at FNA cytology, as illustrated in one of the patients reported in the present study. Regarding specificity, it has been established that physiological expression of the thyroglobulin gene is very strictly restricted to follicular thyroid cells (16-18) and in pathological tissues expression of the $\mathrm{Tg}$ gene has been reported only in DTC.

It may then seem curious that $\mathrm{Tg}$ could be detected in the LNs of patients with evidence of DTC metastasis, as reported in previous studies $(7,14)$. This finding led the authors to define cut-off levels of FNATg above which LN FNATg would be specific of thyroid cells. Theoretically, measurement of thyroglobulin immunoreactivity in non-thyroid tissue can be explained through two hypotheses: contamination of the tissue by circulating serum thyroglobulin or artifact in the method used for detection of thyroglobulin.

In this work, we bring evidence against the first hypothesis: FNATg was not detectable in any of our 26 negative control group of non-thyroidectomized patients who presented with a non-thyroid-related cervical mass. By contrast, FNATg showed high values in each of the 21 patients from the positive control group of patients presenting with a thyroid nodule. These measurements demonstrated that FNATg correctly detected the presence of thyroid cells in the thyroid nodules of the positive control group but was clearly not affected by the circulating serum levels of thyroglobulin originating from the thyroid of the negative control group patients.

We provide two additional lines of evidence against interference of serum Tg in FNATg: calculation of serum
Tg contribution to FNATg using a 'worst-case scenario' and measurement of FNA albumin as a probe for serum protein both demonstrate that serum Tg may significantly interfere with FNATg only in patients with high levels of serum $\mathrm{Tg}$ in whom FNATg has no interest, as these patients generally harbor obvious metastases.

Our findings thus favor the hypothesis that, in all patients who do not have high levels of serum $\mathrm{Tg}$, a detectable level of FNATg in a cervical mass is related to the presence of thyroid cells in this mass. This hypothesis is also favored by the recent studies by Snozek (12) and Cunha (13) who report that cut-off FNATg levels as low as 1 or $3 \mathrm{ng}$ correctly identified DTC LNs. We show evidence for that hypothesis in one patient with low levels of FNATg, who proved to carry oncocytic DTC metastasis with a low expression of Tg as measured by $\mathrm{Tg}$ immunostaining. It is noteworthy that this patient provides the first evidence that a low level of FNATg can be related to a DTC, although oncocytic, as opposed to poorly DTC metastasis (19). Are oncocytic DTC metastases the only possible explanation for low levels of FNATg? In the benign FNA cytology group of our DTC patients, we encountered one patient with a low level of FNATg, whose explanation remains elusive, which represents a weakness of our study. This patient underwent a second FNA after 1 year, which showed an undetectable FNATg and we do not have a definitive histological diagnosis as she did not undergo LN surgery. This patient could represent a rare 'false-positive low FNATg' but alternatively she could carry a DTC micrometastasis that was sampled only in the first FNA. Measurement of FNA mRNATg might prove useful in these difficult cases, although it would need to be validated against histology.

What then could be the explanation of the false-positive 'low FNATg' that have been reported in control patients in other reports $(7,14)$ ? There are a number of different possibilities by which weak signals measured in the immunoassay are related not to the binding of the $\mathrm{Tg}$ antibody to a small concentration of Tg antigen but rather to the non-specific binding of these antibodies to different components of the medium (20). These well-described 'matrix effects' artifacts depend on the antibodies and medium used. Regarding this hypothesis, it is noteworthy that the $\mathrm{Tg}$ dosage kit that was used in this report is different from the kits used in the articles that do report low levels of Tg immunoreactivity in negative control patients.

One of our patients showed high level of FNATg but surgery did not find any DTC metastasis. It should be noted, however, that the FNA cytology of the same LN of this patient was also positive, so that hypotheses other than false-positive LN FNATg should be considered here, including failure of surgery to remove the LN that was punctured, failure of the pathologist to identify this LN or even necrosis of a small DTC metastasis after puncture.

Finally, one limitation of our study is that we cannot exclude false-negative determination of FNATg, as the patients with a negative LN cytology and an undetectable 
FNATg did not undergo LN surgery. It should be noted that in the seminal study of Pacini et al. (7) who used a less specific assay, no DTC metastasis was identified in patients with an undetectable Tg, suggesting that FNATg is very sensitive for the detection of DTC metastasis.

In conclusion, the data we report here support the notion that LN FNATg, using the method and dosage kit that we used, provides a very specific tool for detection of LN DTC metastasis and that even low levels of FNATg can be related to a DTC metastasis.

\section{Acknowledgements}

We thank Dr Mariam Mansour for expert assistance in performing US-guided FNA. We are indebted to all physician members of the thyroid cancer concertation unit for referral of their patients, including endocrinologists (Dr S Biron, M C Baudry, M Berthouze, H Charras, P Corticelli, B Feige, S Pradines, and A Rueff, M Wolff), surgeons (Drs De Marliave, J F Roux, and P Y Brichon), nuclear medicine specialist (Dr J P Caravel), and pathologists (Drs V Bland and A Ciappa).

\section{References}

1 Degroot LJ, Kaplan EL, McCormick M \& Straus FH. Natural history, treatment, and course of papillary thyroid carcinoma. Journal of Clinical Endocrinology and Metabolism 199071 414-424.

2 Frasoldati A, Pesenti M, Gallo M, Caroggio A, Salvo D \& Valcavi R. Diagnosis of neck recurrences in patients with differentiated thyroid carcinoma. Cancer 200397 90-96.

3 Torlontano M, Crocetti U, D'aLoiso L, Bonfitto N, Di Giorgio A, Modoni S, Valle G, Frusciante V, Bisceglia M, Filetti S, Schlumberger M \& Trischitta V. Serum thyroglobulin and 131I whole body scan after recombinant human TSH stimulation in the follow-up of low-risk patients with differentiated thyroid cancer. European Journal of Endocrinology 2003148 19-24.

4 Leboulleux S, Girard E, Rose M, Travagli JP, Sabbah N, Caillou B, Hartl DM, Lassau N, Baudin E \& Schlumberger M. Ultrasound criteria of malignancy for cervical lymph nodes in patients followed up for differentiated thyroid cancer. Journal of Clinical Endocrinology and Metabolism 200792 3590-3594.

5 Crosby JH. The role of fine-needle aspiration biopsy in the diagnosis and management of palpable masses. Journal of the Medical Association of Georgia 199685 33-36.

6 Cignarelli M, Ambrosi A, Marino A, Lamacchia O, Campo M, Picca G \& Giorgino F. Diagnostic utility of thyroglobulin detection in fine-needle aspiration of cervical cystic metastatic lymph nodes from papillary thyroid cancer with negative cytology. Thyroid 2003 13 1163-1167.

7 Pacini F, Fugazzola L, Lippi F, Ceccarelli C, Centoni R, Miccoli P, Elisei R \& Pinchera A. Detection of thyroglobulin in fine needle aspirates of nonthyroidal neck masses: a clue to the diagnosis of metastatic differentiated thyroid cancer. Journal of Clinical Endocrinology and Metabolism 199274 1401-1404.

8 Lee MJ, Ross DS, Mueller PR, Daniels GH, Dawson SL \& Simeone JF. Fine-needle biopsy of cervical lymph nodes in patients with thyroid cancer: a prospective comparison of cytopathologic and tissue marker analysis. Radiology 1993187 851-854.

9 Frasoldati A, Toschi E, Zini M, Flora M, Caroggio A, Dotti C \& Valcavi R. Role of thyroglobulin measurement in fine-needle aspiration biopsies of cervical lymph nodes in patients with differentiated thyroid cancer. Thyroid 19999 105-111.

10 Schlumberger M, Berg G, Cohen O, Duntas L, Jamar F, Jarzab B, Limbert E, Lind P, Pacini F, Reiners C, Sanchez Franco F, Toft A \& Wiersinga WM. Follow-up of low-risk patients with differentiated thyroid carcinoma: a European perspective. European Journal of Endocrinology 2004150 105-112.

11 Pacini F, Schlumberger M, Dralle H, Elisei R, Smit JW \& Wiersinga W. European consensus for the management of patients with differentiated thyroid carcinoma of the follicular epithelium. European Journal of Endocrinology 2006154 787-803.

12 Snozek CL, Chambers EP, Reading CC, Sebo TJ, Sistrunk JW, Singh RJ \& Grebe SK. Serum thyroglobulin, high-resolution ultrasound, and lymph node thyroglobulin in diagnosis of differentiated thyroid carcinoma nodal metastases. Journal of Clinical Endocrinology and Metabolism 200792 4278-4281.

13 Cunha N, Rodrigues F, Curado F, Ilheu O, Cruz C, Naidenov P, Rascao MJ, Ganho J, Gomes I, Pereira H, Real O, Figueiredo P, Campos B \& Valido F. Thyroglobulin detection in fine-needle aspirates of cervical lymph nodes: a technique for the diagnosis of metastatic differentiated thyroid cancer. European Journal of Endocrinology 2007157 101-107.

14 Baskin HJ. Detection of recurrent papillary thyroid carcinoma by thyroglobulin assessment in the needle washout after fine-needle aspiration of suspicious lymph nodes. Thyroid 2004 14 959-963.

15 Ahuja A \& Ying M. Sonography of neck lymph nodes. Part II: abnormal lymph nodes. Clinical Radiology 200358 359-366.

16 Van Herle AJ, Vassart G \& Dumont JE. Control of thyroglobulin synthesis and secretion (first of two parts). New England Journal of Medicine $1979301239-249$.

17 Van Herle AJ, Vassart G \& Dumont JE. Control of thyroglobulin synthesis and secretion (second of two parts). New England Journal of Medicine 1979301 307-314.

18 Hansen C, Gerard C, Vassart G, Stordeur P \& Christophe D. Thyroid-specific and cAMP-dependent hypersensitive regions in thyroglobulin gene chromatin. European Journal of Biochemistry 1988178 387-393.

19 Boi F, Baghino G, Atzeni F, Lai ML, Faa G \& Mariotti S. The diagnostic value for differentiated thyroid carcinoma metastases of thyroglobulin (Tg) measurement in washout fluid from fine-needle aspiration biopsy of neck lymph nodes is maintained in the presence of circulating anti-Tg antibodies. Journal of Clinical Endocrinology and Metabolism 200691 1364-1369.

20 Wood WG. 'Matrix effects' in immunoassays. Scandinavian Journal of Clinical and Laboratory Investigation 1991205 105-112.

Received 29 January 2008

Accepted 1 February 2008 